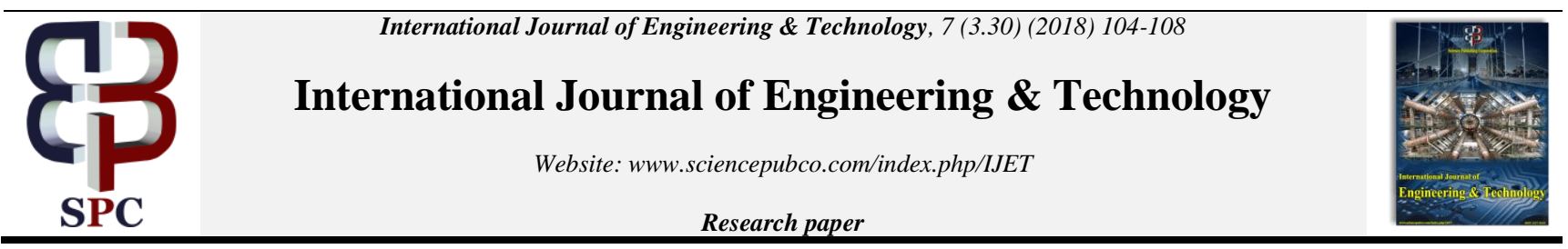

\title{
Admissibility of Iqrar as Evidence: the Issue of Voluntariness from Syariah Principles Perspective
}

\author{
Ahmad Azam Mohd Shariff ${ }^{*}$, Ramalinggam Rajamanickam ${ }^{1}$, Parveen Kaur Harnam Singh ${ }^{1}$, Siti Khadijah Md \\ Lazim $^{3}$, Anna Sofea Nurol Adzmi ${ }^{1}$, Lim Xin Xian', Muhammad Faris Haikal Mad Zahudi ${ }^{1}$,
} Tg. Noor Azira Tg. Zainudin ${ }^{1}$

${ }^{1}$ Faculty of Law, Universiti Kebangsaan Malaysia

*Corresponding authorE-mail: aazam@ukm.edu.my

\begin{abstract}
Iqrar is a form of bayyinah or evidence which could be tendered during trial at the syariah court. The syariah evidential principles renders it relevant and admissible with varying effect. Iqrar sorih or confession, once admitted by court, would become binding against the accused. In such a scenario, the court may convict the accused based on such confession without any need for further proof. On the other hand, the court may also admit an admission or iqrar kinayah but it could never convict the accused based on such admission alone. In other words, based on admissibility of such admission, a court could only convict the accused should such admission is further corroborated and strengthened by other evidence. This article however observes that the strength of a confession very mush depends on voluntariness of the maker of the confession. There is also some confusion among syariah practitioners as regards to the difference between both forms of iqrar. The conducted research is pure legal and qualitative in nature. Data and materials on iqrar confession and admission are collected via library research method. These data and materials are then analysed using critical and content methodologies.. This article analyses the relevancy and admissibility of iqrar confession and admission in the eyes of syariah evidential principles. It then strives at identifying problems relating to its admissibility and interpretation. This article eventually offers some ideas on ways of avoiding future misinterpretation of iqrar while simultaneously looking into some ideas on how to improve its application.
\end{abstract}

Keywords: Iqrar, Confession, Admission, Syariah Evidential Principles, Relevancy, Admissibility.

\section{Introduction}

Iqrar in its literal meaning is declaration or admission. It is a relative proof in that it affects only the person making such a confession. Confession is an acknowledgment of guilty by a person charged with a crime and it is also one of the important legal methods to find someone guilty [1]. When a person is accused with a crime and he makes a confession about his offence, the judge must convict the accused if the judge feels satisfy that the confession made by the accused is voluntarily and without any doubt or ambiguity.

In Islamic law, there are legal basis for every principle of law which can be found in the primary source and secondary source. The primary source is the Holy Quran and Sunnah of the Prophet Muhammad (S.A.W). The secondary sources comprises Ijma, Qiyas, Istihsan, Customs among others. There are a lot of verse in Al Quran that Allah mention about confession by a guilty person [2].

\section{Definition of Iqrar}

There are various definitions of iqrar from various school of Mazhab. The Shafiee school defined iqrar as informing a right of another by informal against himself. The Shafiee school also defined iqrar as making a confession about something that does not belong to the person making it. Iqrar as defined by the Hanafi
School means the avowal of the right of another upon one $e^{\text {ec }}$ self. Iqrar is made by someone to admit the right of another against himself. The accused is under some obligation to another person in respect of some right. Therefore, Iqrar is a specific admission as a means of proof to clearly indicate a right or interest of another against oneself, or to admit of an offence or liability against a confession, of a person that he has an obligation to another person, oneself [1].

The basis of confession as means of proof can be found in the $\mathrm{Al}$ Quran and the Sunnah. In the holly Quran, in surah Al-Nisa verse 135 says „O ye, who believe, stand out firmly for justice, as witnesses for Allah, even as against yourselves ${ }^{\text {ee. }}$ Confession has been recognized as a source of conclusive proof of right by the Holy Quran and Sunnah. There are three important elements that need to be fulfilled under Iqrar. First, muqarrun which means the person who makes such confession. Second, muqarrun lahu which means the person in whose favour the confession is made. Third, muqarrun bihi which means the subject matter of confession.

\section{Conditions of a Valid and Admissible Iqrar}

According to the majority of Fuqaha, a valid Iqrar must consist four elements; namely, conditions of the person making such confession (Muqarrun), conditions of the person in whose favour the confession is made (Muqarrun lahu), conditions of the matter which is the subject of the confession (Muqarrun bihi) and conditions of the terms of sighah. 


\section{a) Conditions of the Person Making Such Confession (Muqarrun)}

The muqirrun must be a sane person because a person who is not sound mind cannot be imposed the obligations of the Sharieah. Besides that, as according to section 18(1) (Federal Territory), the muqirrun must must be a mumayyiz which the general rule is children are not qualified to make admissions unless their guardians have permitted them to carry on business and deed with people as they are deemed to be on par with adult and their admission only restricted to mu "eamalat matters such as debts, trusts, loans, business etc.

The muqirrun should be aqil baligh. This is according to section 18(1) of the Syariah Evidence Act(Federal Territories) Act. Unless otherwise codified, iqrar cannot be made by a child, an insane person or wali or wasi on behalf of their dependents. This is stated in section 18(d) to (e) of the Syariah Evidence Act. However, a child which is already mumaiyiz, that has been given permission to to trade and deal with other persons can make a valid iqrar. This is according to section 18(2) of the Evidence Act.

The muqirrun should also be a free person, which is free from the bondage of slavery. However, the iqrar of a slave is also valid for all matters if he has been given permission by his master to engage in trade. Under Islamic law, the person who makes an admission must be clear from all doubts or suspicions. Furthermore, the Iqrar shall be made seriously and intentionally through the use of serious language. Thus, such admission made in a playful manner is inadmissible.

The muqirrun shall not be under interdiction, which is the person who makes an admission shall be a person who is not prohibited from administering his property, e.g. a bankrupt (as stated under section 18(6) of the Islamic Evidence Act (Federal Territory) 1989). In addition, the person who makes an iqrar and the subject matter of the iqrar must be identified to ensure the person can be subjected to claim another condition is the muqirrun must be told the consequence of his iqrar, otherwise it will be an unvalid iqrar.

The most important element is the iqrar must be made free from any elements of coercion and it must be made with full consciousness. Thus, an iqrar which is obtained by force or when the person is unconscious, asleep or during amnesia in invalid and inadmissible. The Islamic legal maxim which expressed this condition is al-,Ikraah yamna al-iqraar (coercion prevents the validity of confession).

Voluntary iqrar is clearly stated in several authorities. According to a hadith where The Prophet (p.b.u.h.) was reported to have said: „My Ummah are excused for acts which they commit or omit out of mistakes, forgetfulness and under coercion. " Furthermore, Article 1575 of the Majelle provided that. "With regard to an admission, the consent of the person who makes the admission is a condition. Therefore an admission made by compulsion or force is not good." This is in line with section 18(5) of the Evidence Act (Federal Territory) 1989 which state that an admission shall be made voluntarily without coercion. Section 18(7) of the same act further provides that an admission made under the influence of intoxicants shall not be accepted in cases liable to hudud in accordance with Islamic law.

In conclusion, a confession obtained by way of coercion is inadmissible evidence as the accused may telling lies against himself.

\section{b) Conditions of the Person in Whose Favour the Con- fession is Made (Muqarrun Lahu)}

The are several conditions for muqirrun lahu, first, the muqirrun lahu must be present at the time of the submission or still alive. Non existence of the muqirrun lahu will render the iqra null and void. Secondly, the person must also be eligible to accept the aforesaid of iqra. Thirdly, the muqirrun lahu must be identified. Fourthly, the person must be a person who have a reasonable ground in order to get the subject matter of the iqrar. [3].

\section{c) Conditions of the Matter Which is the Subject of the Confession (Muqarrun Bihi)}

The subject matter of the iqrar must be identified to ensure the matter can be claimed by the claimant.

\section{d) Conditions of the Terms of Sighah}

Consummation is the only condition for sighah to be implemented by the parties. Referring to Malaysian Evidence Act 1950, the most crucial thing is the ability is to understand the question or give rational answer which is quite similar with shariah but under Islamic law the scope, effect and some conditions may be wider as discussed above.

\section{Determining Voluntariness in a Confession}

\section{a) Detailed Confession}

In the book Fiqh Sunnah, a hadith is quoted whereby the Prophet require confessor to give detailed admission and confession in order to avoid any shadow of doubt. The detailed confession must fulfill all the ingredients of an offence to be admissible as evidence. This requirement is to safeguard the voluntariness of confession. In other hand, in respect of civil law, it just needs to be a substantive confession. The Admission and Confession must be explicit and there should be no ambiguity in it.

It is shown in the incident where Prophet (PBUH) asked Ma,az Ibn Malik "Are you insane?" He said "No". The Prophet (PBUH) then asked" you might have kissed her?" He replied "No, I had intercourse with her." The Prophet (PBUH) then asked: "Have you made penetration?" He said, "Yes". Then the Prophet (PBUH) asked, "Do you know what is Zina?" He said, "Yes, that what a husband does legally with her, I have done that illegally." The Prophet $(\mathrm{PBUH})$ also turned his face from him in order to give him the opportunity of retraction, but despite this he came again and again till confessed four times. After this the Prophet (PBUH) ordered to stone him to death. (Sahih al Bukhari, under the section entitled Kitab al Hudud)

\section{B) Confession to be Made Four Times}

According to Imam Abu Hanfah and Imam Ahmad four times confession is vital for proving the crime and punishment. Hudud crimes such as adultery require four witnesses; therefore confession must be made four times to replace four witnesses. Four times confession can ascertain the voluntariness of the confession. In Sunan Abu Daud, under the chapter of Hudud, it is pointed out that there is a hadith whereby Ma'iz ibn Malik came to the Prophet (peace be upon him) and admitted fornication twice. But he drove him away. He then came and admitted fornication twice. He (the Prophet) said: "You have testified to yourself four times, take him away and stone him to death."

However, according to Imam Malik and Imam Shafi if a person confesses one time only in an authorized court then it is sufficient for inflicting on him the penalty.

In the book Sunan Abu Daud, under chapter Hudud, a hadith is quoted whereby the prophet (P.B.U.H) asked Unais to go and ask the woman whether she had committed zina and stoned her to death if the answer was affirmative. She confessed to Unais that she committed the wrongdoing and she was stoned to death.

The book of Tirmizi, under the chapter of al Hudud, it is pointed out that the first opinion on four times confession is preferable as 
the burden of proof for Hudud crime must be "yakin" (beyond reasonable doubt). The Prophet (P.B.U.H) said "Repeal the Hudud crimes to the extent you can."

According to section 17(2) of Syariah Court Evidence (Federal Territories) Act 1997 (Act 561), an iqrar shall be made-

\section{(a)}

in Court, before a Judge; or

(b) outside Court, before two male witnesses who are 'aqil, baligh and 'adil.

Therefore, under this section, an confession is not required to be made four times as long as the accused admit his guilt in front of a Judge or alternatively admission done before two male witnesses who are 'aqil, baligh and 'adil outside the Court.

\section{c) Confession Must be Specifically Referring to the Al- leged Crime}

One of the conditions for the admissibility of a confession is that the confession must be specific to the wrongdoing. In the celebrated book of Sahih Bukhari, under the section Kitab al-Maharibin min ahl al-Kufr wal riddah under the part Aqarra bil Had wa lam yubayyin, a hadith is quoted which means:

A man came and said, "O the Messenger of Allah! I have committed a legally punishable sin, please inflict the legal punishment on me." The Prophet (peace be upon him) did not ask him about what he had done. The time for the prayer became due and the man offered prayer along with the Prophet (peace be upon him) and when the Prophet (peace be upon him) had finished his prayer, the man again got up and said, "O the Messenger of Allah! I have committed a legally punishable sin; please inflict the punishment on me according to Allah's laws." The Prophet (peace be upon him) said, "Haven't you prayed with us!" He said, "Yes". The Prophet (peace be upon him) said, "Allah has forgiven your sin." If the confession of accused did not specify the offence he committed, the judge cannot screen it for him because the law is that confession must be specific and not vague. This is in line with the principle nulla poem sine lege which means "no penalty without a law". The latin maxim simply means one cannot be punished for doing something that is not prohibited by law where no conduct may be held criminal unless it is precisely described in a penal law. Therefore, by including specific confession as one of the ingredient to ascertain voluntariness of confession, it can restrict criminal sanction.

\section{c) Sanity of the Accused to be Ascertained}

In a hadith reported in Sunan Abu Daud, under the section entitled Kitab al Hudud part Bab al Rajm, Hadith 4421 (3718), an accused, after confessing four times, the Prophet (peace be upon him) asked his Companions whether the accused is mad. They replied that the accused had no defect in him. This question of the Prophet was to safeguard the right of the accused to confess free from threat, inducement and promise in order to achieve the desired effect of legality.

According to the celebrated book of Fiqh al Sunnah, he confession/ Admission of a child, insane and sleeping person is not admissible. The Holy prophet (PBUH) said" Three persons have been exempted from any liability, the minor until he attains puberty, the insane until he attains sanity and the sleeping person until he awakes."

Section 18 Syariah Court Evidence (Federal Territories) Act 1997 (Act 561) stated the conditions for Admissibility of iqrar.

(1) The following iqrar is inadmissible:

(a) iqrar of a person who is not 'aqil baligh;

(b) subject to subsection (2), iqrar of a minor;

(c) iqrar of a lunatic or a mentally retarded person $\left(m a^{\prime} t u h\right)$;
According to Section 18(1) (a) and (b), confession or admission of a minor cannot be admissible because capability of a child to understand the weight of the confession and admission and the punishment is doubtful. Under section 18 (1) (c) also clearly exclude the confession and admission of an insane person because his mental condition affect his ability to understand what he said.

\section{Iqrar Sorih or a Confession: its Relevancy and Admissibility}

Iqrar Soreh is the truest form of confession in Islamic Evidence. It is comparable to a confession in Evidence law as defined under Section 17 (2) of the Evidence Act 1950. Under this chapter, the admissibility and relevancy of iqrar soreh will be discussed.

There are some sources that attest to the admissibility and relevancy of this form of iqrar, it is in fact one of two forms of confessions which is accepted as primary evidence, if all elements are fulfilled. Iqrar in itself has its stand as the highest form of evidence available in Islamic evidence, this rests itself in actuality on iqrar soreh.

In terms of its stand, there are scholars who suggest that iqrar under section 17 (1) that is "iqrar yang dbuat oleh tertuduh sama ada secara bertulis, lisan mahupun isyarat, yang menyatakan bahawa dia mempunyai obligasi ataupun tanggungan terhadap seseorang itu mengenai sesuatu hak", which means that iqrar made by an accused either by way of oral statement, written statement or signals which state his obligation or liability to a person in regards to a right. This provision is said to be the provision for iqrar soreh. According to Dr. Ahmad Azam, iqrar under Section 17 (1) does not need corroboration to convict an accused of a crime. It is otherwise known as confession as opposed to admission which comes under section 17(3) and is known as iqrar kinayah [4].

The probative value of an iqrar soreh is high as it is the purest form of iqrar. Under section 17(2)(a) of the Syariah Evidence Act, the best form of iqrar would be that which is made in the presence of the Judge and if it is made outside of the court, then it is admissible but there has to be two witnesses which are aqil baligh. This is according to section 17(2)(b). This means that the strength of iqrar soreh is further established if the confession is made in the presence of the Judge.

An iqrar soreh as it stands is a confession made which is legal in nature. Justice is a paramount aspect in Islamic law and it views confessions properly and legally so made as legal and admissible [5]. An example of the legality and admissibility of iqrar soreh lays in the Quranic verse 2: 282, “...when you contract a debt, write it down...", where manifesting a confession in regards to rights of others in one ${ }^{e s}$ possession is considered an admissible confession.

In the Federal Territories Islamic Evidence Act, there is a provision on the admissibility of confession as evidence, under Section 18 of the Act. This provision proves that iqrar is on the face of it admissible. The admissibility of it is only question under specific circumstances.

The issue that arises in the relevancy and admissibility of confession is such that a confession may be rendered invalid when it is made through coercion. Such a confession may be relevant but it is inadmissible. This is also codified under Section 18 (1) (e) of the Islamic Evidence Act, "iqrar yang tidak dibuat secara sukarela". This would mean that this form of iqrar is not considered iqrar soreh.

As a whole, iqrar soreh is a strong form of evidence, and where relevant, it is admissible. It is also a form of evidence which does not need supporting evidence. This does not though connote that it is a common form of evidence found in the corpus of Islamic evidence. It is in fact a rare form of admissible evidence, because of its stringent requirements. Voluntariness here would be one of them. 
In practice, the requirements of an iqrar is found and assessed according to the Syariah Evidence Act. Although voluntariness is an issue in theory, according to Yang Arif Abu Suffian, in reality evidence that is given voluntarily or involuntarily is not a main issue before conviction of a person or punishment is meted out [6]. To further understand iqrar soreh, it has to be noted that iqrar soreh is in a precarious position. A confession is only valid when there is certainty to its truth. The conviction on the basis of confession is only meted out when there is no doubt whatsoever as to the guilt of the accused. This is evidenced in case law. For instance, in the case of Pegawai Pendakwa MUIS lwn. Haji Adib Datuk Said Besar Sigoh Jurnal Hukum No. 234/187, the accused was charged with having sex out of wedlock with a woman named Raini. In this case, Raini confessed but the accused did not. The Kota Kinabalu Syariah Court held that due to the lack of witnesses and that the accused retracted his initial confession, the accused could not be convicted. The judge further went on to state that the validity of the iqrar soreh depends on the value of the iqrar. If the iqrar fulfils all the requirements, then it may be admissible, if it does not, then it is not admissible. To further illustrate the strict nature of an iqrar soreh, in the case of Haminahbe lwn. Samsudin Jurnal Hukum 8/78, p 71 , the judge dismissed the iqrar evidence on the basis that there were insufficient evidence.

The strength and admissibility of the iqrar evidence is also dependent on the evidence available to the court or the evidence tendered in court. In the case of Pendakwa Mahkamah Kadi Perak lwn. Ajmee Hamid dan Siti Fariha Sulaiman 245/89 Jurnal Hukum hlm 49, the two accused were charged with committing zina. At the time of the trial, the prosecution did not tender any witnesses. As both witnesses confessed at the time that the charges were read to them, the court convicted both of the accused. Here, both witnesses voluntarily confessed and therefore this evidence was admissible. Further, in the case of Pendakwa lwn. Awang Mat Isa J/48 Jurnal Hukum hlm. 80, the woman confessed and was convicted with an RM400 fine and prison sentence of four days. There is also a strict admissibility for iqrar soreh. It should be noted that once the confession is made, it cannot be retracted. The confession is not deemed involuntarily although it has been retracted. This was established in the criminal appeal case of Faridah lwn. Pendakwa Jenayah Kelantan 2/1978 Jurnal Hukum, hlm 89 , where the iqrar evidence was admitted although the accused retracted it.

All in all, iqrar soreh is stringent and strict in its application. It has to be absolute and unconditional to be admitted as evidence in court. This was established in the case of Pendakwa Syarie lwn. Jaafr bin Sudin \& Seorang Lain 3/90 Jurnal Hukum, p 181. This would mean that it has to be free from elements of involuntariness.

\section{Relevancy and Admissibility of Iqrar Kina- yah}

The definitions of the word iqrar laid down in the Evidence Act of Sharia Courts (Wilayah-Wilayah Persekutuan) is not clearly defined of its scope and meaning thus creating a lot of interpretations among Islamic law practitioners according to their own understanding and principles. However, in understanding iqrar kinayah, majority of the practitioners held down to definition under Section 17(3) of Evidence Act of Sharia Courts (Wilayah-Wilayah Persekutuan) which stated that this kind of admission is a form of mere confession, not leading to a guilt confession as admission under Section 17(1) of the Act.

Talking about the relevancy of this admission, there ${ }^{e s}$ an authority derived from the Quran in Surah Al-Qiamah verse 14 which stated that a man could be his own witness leading to his own prosecution, although he"es been giving excuses to defend himself. In Islam, we believe that during the Judgement Day, the parts of a man"s body will be able to talk and function as witness to proof one"s actions during his life. This makes iqrar stands as a relevant evidence to the Court as it is coming from the accused himself.
Iqrar kinayah in the eyes of the Court is acknowledged as a form of qarinah (proof). However, it will only be admissible to the Court if it is supported with other related evidences in order to make it stand as a qarinah. Looking at the degree of iqrar, this type of admission could not be used to prosecute an accused directly without being supported by other related evidences, vice versa with admission under Section 17(1) of the Act which permits an accused to be prosecuted directly on the basis of the admission. This is stated by Tuan Haji Che Zam Zam Bin Che Man, a Sharia prosecutor of Jabatan Agama Islam Melaka in an interview regarding the Procedures of Sharia Case Prosecution on 17 and 20 December 2010. In addition, an iqrar must be ensured to fulfill the conditions under Section 18(1) of the Act before being submitted to the Court.

There are also views saying that admission under Section 17(3) of the Act is an admission made by someone else on behalf of the accused and it has nothing to do with a guilty confession and mere confession itself. It can be understood as an aid to assist the Court in delivering a proper judgement, without affecting the image of the accused as the admission is said to have nothing in connection with any form of confession. Tuan Syeikh Amiruddin Putra Bin Zainol Abidin, a Sharia Court judge of Sharia Court Kuala Muda, supported this view.

In conclusion, iqrar kinayah has no problem to be submitted to the Court as a form of proof in order to prosecute oneself but must be supported with other related evidences and relevant to the matter in dispute. It would still be accepted and treated as a persuasive authority to help the Judge in making their best decision for the conflict happened.

\section{Comparison between Civil Evidence and Syariah Evidence on Voluntariness in Confes- sion}

In this article, the literature on voluntariness in confession and its admissibility has been discussed. It can be seen that there are some differences between the two. This aspect will be delved into in this segment of the article.

\subsection{Theoretical Similarity}

Under Syariah Evidence Law, a confession must be free from threat, inducement and promise which is similar to the voluntariness test in Civil Evidence Law. A confessor must understand the consequences of his confession. If a confession is made under the promise to lessen the punishment, then justice might not be upheld as the parties (the accused, person in authority or judge) are bound by the promise. Based on Surah al-Qiyamah ayat: 14 "Bahkan manusia itu menjadi saksi terhadap dirinya sendiri ", it means that a confessor is a witness of truth for himself. Therefore, a confession of an accused before a Judge is binding.

\subsection{Practical Similarity}

Section 24 of the EA states that when a person makes a confession to a "person in authority" under inducement, threat or promise then that confession is rendered involuntary. In the Islamic law position, the approach is similar.

According to Yang Arif Abu Suffian, the principles of Syariah law have also adhered to the fact that there should be no elements of force in confession more so for confessions made under force to a person in authority. [6] In the case of, Pendakwa Mahkamah Syariah Perak lwn. Ishak dan Fatimah Jurnal Hukum 48/79, p 308 . the Court did not convict the accused based on the confessions of the two accused to the religious authority. This shows that there is a similarity in the position of Section 24 of the EA and the syariah law. 


\subsection{Practical Differences}

There are similarities between voluntariness in confession in Civil Evidence Law and Confession in Islamic Evidence Law. The difference lies in what leads to involuntary confession.

\subsubsection{Requirements under Section 24 of the Ea}

In Civil Evidence, confessions are voluntary unless there is inducement, threat or promise as codified under section 24 of the Evidence Act 1950. In terms of case law, there is also the additional concept of oppression which can also lead to a confession being involuntary. For Islamic Evidence, however, according to His Honourable Abu Suffian, there are certain requirements that have to be adhered to for iqrar in terms of the right of Allah s.a.w and the right of humans, that is, having intelligence or sane mind, mumaiyiz, no additions in what is being confessed, the iqrar is given willingly and by obeying, the person who is giving the confession is known and the substance of the confession is also known and understood [6]. These requirements are further established under Section 18 of the Shariah Evidence Act. The difference here lies in the fact that the Syariah

Evidence Act lays down confessions that can be admissible but the EA does not. On the other hand, the EA has a specific provision which states that inducement, threat and promise render a confession involuntary and therefore inadmissible. The Syariah Evidence Act does not have such a provision. Further, the aspects that render a confession involuntary in the civil context differs from the Syariah context as already discussed.

According to section 24 of the EA, an accused must confess to a person in authority. A person is authority can be anyone has authority or control over the accused or over the proceedings or prosecution against him such as a manager of an estate was the person authority in relation to an estate worker as stated in PP v Naikan 1 MLJ 147. However, under 17(2) of Syariah Court Evidence (Federal Territories) Act 1997 (Act 561), iqrar can be made in front of a Judge or alternatively iqrar done before two male witnesses who are 'aqil, baligh and 'adil outside the Court.

\subsubsection{Requirements for Voluntariness}

In civil evidence, voluntariness is needed to ensure that a confession is valid. Further, the voluntariness has to be proven. The case of Dato Mokhtar Hashim \& Anor v Public Prosecutor 2 MLJ 232. cited and applied the principles in the case of Director of Public Prosecutor v Ping Lin AC 574 whereby the admissibility of confessions depends on the fact that the prosecution is able to prove without reasonable doubt that the confession was given voluntarily. Here, it is clear that proving voluntariness is important in convicting someone based on confessions in civil evidence. The position of civil evidence differs from syariah law. In iqrar, it needs to be voluntary and reda. Iqrar obtained by force or when a person is unconscious or asleep is invalid. This shows the difference in position in civil law and syariah law [6].

\subsection{Suggestion for Improvement}

In the opinion of Yang Arif Abu Suffian Bin Abu Yaziz, the improvements that can be made to the syariah evidence law in regards to confessions is to detailing the process of confession through the creation of a method or process (SOP) that can assist the Judge of the Syariah Court in making decisions or determining the admissibility of a confession made in Court or outside the Court [6].

\section{Suggestion and Concluding Remarks}

In conclusion, voluntariness is a key aspect in admissibility of evidence. The nuances and important elements of voluntariness in confession in syariah law has been fleshed out in this article. In discussing voluntariness in confession in Islamic law, the iqrar that is concerned is iqrar soreh. Iqrar soreh is a strong form of evidence on its own, but when there is the element of involuntariness, the admissibility and probative value of the iqrar is jeopardized. All in all, the corpus of Islamic legal materials and provisions on confession evidence needs to expanded and increased to ensure more clarity in determining voluntariness in confession. The law as it stands frowns upon involuntariness but the law in itself needs a revamp.

\section{References}

[1] Mohd Ashraf Hashim (2001), "Tahap Pembuktian di dalam Keskes Jenayah: Kajian Perbandingan Antara Undang-undang Islam dan Sivil" 9(1), Jurnal Syariah 13-32.

[2] Saedon, Mahmud (1992), Keterangan \& Hukum Memberikannya. Kuala Lumpur: Penerbit UM.

[3] Mohd Nasran Bin Mohamad (1994), Islamic Law of Evidence in Confession (Iqrar): Definitions and Conditions" Islamiyyat 84.

[4] Ahmad Azam Mohd Shariff (2011), Prosedur pendakwaan jenayah syariah: analisis ke atas peruntukan undang-undang di bawah Akta Prosedur Jenayah Syariah (Wilayah-wilayah Persekutuan) 1997 dan Akta Keterangan Mahkamah Syariah (Wilayah-wilayah Persekutuan) $1997^{\text {ce }}$ Jurnal Undang-Undang dan Masyarakat 6.

[5] Mohamad Akram Shair Muhammad (2012), Confessions under Malaysian and Islamic laws: a comparative evaluation "e 6 (11) Australian Journal of Basic and Applied Sciences 22, 42.

[6] Abu Suffian Bin Abu Yaziz (2017), Voluntariness and Admissibility of Confession As Evidence in Malaysia. Former Syariah Court Judge, Ketua Pendaftar Mahkamah Syariah Melaka. 26 November 2017. 